\title{
Hundi, kitse ja kapsapea üle jõe viimine. ATU 1579 metamorfoosid
}

Piret Voolaid

\begin{abstract}
Teesid
Artiklis on vaatluse all Antti Aarne, Stith Thompsoni ja Hans-Jörg Utheri rahvusvahelises jututüübikataloogis numbriga ATU $1579^{1}$ registreeritud süžee (Hundi, kitse ja kapsapea üle jõe viimine) käibimine jutu ja mõistatusena ning traditsioonilistest pärimusliikidest lähtuvad vormid, mis on seda süžeed aegade jooksul ümbritsenud. Lisaks jutu- ja mõistatusežanrile on tänapäeva tehnoloogilises maailmas süžee leidnud laialdast rakendust interaktiivse arvutimänguna. Ühe tüübisüžee erinevaid vorme ja eesmärke võib vaadelda tänapäeval ka kui folkloori ja folklorismi kokkupuutepunkte.
\end{abstract}

Märksõnad: arvutimängud, folkloori lühivormid, folklorism, internetifolkloor, mõistatused, narratiivid

Folkloorse ainese uurijad seisavad sageli silmitsi traditsioonilisest liigitamisest tulenevate vastuoludega. Kui pärimusliigi määratlemisel esineb raskusi ja liigipiirid tunduvad hajusad, pole probleem mitte niivõrd liigitusele allumatutes üksustes, kuivõrd uurijate liigikeskses käsitlusviisis (Ben-Amos 1982: 11). 2001. aastast alates rajatud mõistatuste perifeeria andmebaaside ${ }^{2}$ arhiivikeskne ülesehitus järgib traditsioonilist filoloogilist käsitluslaadi, mis tavatseb rühmitada rahvaluuletekste tüüpideks ja rahvaluuleliikideks. Ent pärimusliik on muutuv vorm ja pärimustekstidele on tihtipeale iseloomulik paljudest teguritest (sh kasutus-, esituskontekstist tulenevaist) tulenev nii tüübi- kui ka liigipiiride ületamine.

Pärimuse valdaja kasutab elavas esituses klassikaliste rahvaluuleliikide vormimalle alateadlikult, kindla liigi ja tüübi etteantud kuju jäik järgimine on temale ebaoluline. Pigem mõjutab teda pärimuse sisuline motiivistik, mis realiseeritakse sobiva pärimusliigi poolt ette antud vormi kaudu. Praktikas võib folklooritekstil tihtipeale olla ühel ja samal ajal seoseid eri pärimusliikidega. On uurijaid, kes folkloorse ainese süstematiseerimisel kasutavad liigikesksete rigiidsete mõistete kõrval, nagu näiteks tüüp ja variant, sisumotiive ja teemasid, mis võivad rännata liigist liiki, osutades

http://haldjas.folklore.eeltagused/nr28/voolaid.pdf 


\section{Piret Voolaid}

sel moel liigipiiride määramise kitsaskohtadele (vt nt jutu ja ütluse vahekorrast Krikmann 2005: 91; mõistatuse ja anekdoodi vahekorrast Šmeljova \& Šmeljov 2002: 97; vanemate ja uuemate rahvalaulude uurimisel tüübi asemel teema, variandi asemel laul Ehin 2004: 10-11). Mida aga teha, kui uurija/arhiveerija ees on materjalimassiiv, mis on kogutud pikkade aegade vältel ning paigutatud nendesamade pikkade aegade vältel traditsiooniks saanud ja kõige sobivamana tundunud liigi-, tüübi-, redaktsiooni- ja variandikesksesse arhiivisüsteemi? Selle süsteemi järgi saab materjali sisust ja teemast rääkida just klassikaliselt, st liigituslikult pinnalt. Kindlasti tuleb uurijal näha staatilisest arhiivimaterjalist kaugemale.

Käesolevas artiklis on vaatluse all Antti Aarne rajatud ning Stith Thompsoni ja hiljuti ka Hans-Jörg Utheri täiendatud jututüübikataloogis (ATU) numbri 1579 all registreeritud süžee ja seda aegade jooksul ümbritsenud muudest pärimusliikidest lähtuvad vormid.

Kümmekond aastat tagasi võidukäiku alustanud arvutiajastul on ATU 1579 põneva metamorfoosi kaudu taas laiemasse huviorbiiti tõusnud. Ühelt poolt on siin tähtis sama sisumotiivi kandumine minevikust tänapäeva, ent teiselt poolt ületab pärimustekst pidevalt rahvaluule piire, olles kontaktis oma ajastu teiste kultuurivormidega. Nagu see suuliselt käibel olnud tekst sattus varem paljudesse lasteraamatutesse ja kooliõpikutesse, nii satub see tänapäeval internetti. Selle tüübi elujõulisus on tagatud pideva kohanemisvõimega nagu käesolevagi näite puhul. Rahvaluuleteadlased käsitlevad kultuurivormide omavahelisi seoseid mõistete folkloor ja folklorism või folkloori teine elu kaudu.

\section{Tüüp ATU 1579 eesti traditsioonis}

Tüübi nr 1579 kirje ATU-kataloogis on eesti keelde tõlgituna järgmine:

Hundi, kitse ja kapsa üle jõe viimine (Carrying Wolf, Goat and Cabbage across Stream). Mees peab ületama jõe paadiga, millesse mahub peale tema ainult üks kaaslane. Ta peab üle jõe viima hundi (lõvi, šaakali), kitse (lamba) ja kapsapea (heinakuhja, kõrvitsa). Mees peab tegutsema nii, et samal ajal, kui ta ise on paadiga jõel, ei sööks hunt ära kitse ega kits kapsapead. 
Ülesandel on kaks lahendust: (1) ta viib kitse üle jõe, seejärel viib hundi üle jõe ja toob kitse tagasi, (2) ta viib kitse üle jõe, seejärel viib kapsa üle ja toob kitse tagasi; ta viib hundi üle jõe ja tuleb kõige lõpuks kitsele järele.

Tüüp paikneb kataloogi teises köites Rumala kolli jutud, anekdoodid, naljandid ja vormelmuinasjutud (Tales of Stupid Ogre, Anecdotes and Jokes and Formula Tales) naljandite ja anekdootide peatükis "Kavala mehe" (Clever man, nr-id 1525-1639) alajaotuses. Asudes küll juttude hulgas, moodustab mehe ees seisev ülesanne justkui mõistatuse narratiivse küsimuspoole ja vastuseks pakutakse skeemis välja kaks lahendust. Rahvusvaheliselt tuntud arhailise süžee väljendamiseks sobivad seega nii narratiivi vorm kui ka mõistatusele omane küsimus-vastus-vorm. Ka Eesti Rahvaluule Arhiivi käsikirjades leidub sama süžeega mõlemasse rahvaluuleliiki kuuluvaid üleskirjutusi. Puhtnarratiivse vormi illustratsiooniks on Matthias Johann Eiseni kogust pärinev rahvajutt:

Korra tahtis mees lootsikuga üle jõe sõita sikk, koer (hunt) ja kapsapea kaasas. Lootsik kandis ainult mehe ja ühe neist. Oleks mees kitsega üle jõe läinud, oleks hakatus küll hea olnud, aga kui mees oleks kapsaid ehk koera läinud tooma, oleks kits teisel pool kapsad söönud ehk koer (hunt) kitse murdnud. Mehel hea nõu kallis. Viimaks sai ometi õige aru kätte. Viis kitse üle jõe, tuli tagasi, viis koera, aga tõi ühtlasi teises kaldas kitse jälle tagasi kapsaste juurde. Pani kapsapea lootsikusse, jättis kitse kaldale. Viis kapsapea koera juurde -, ja kits ei söönudja sõitis nü̈̈d kitse järele. Viis viimaks kitse teist korda üle jõe. Nüüd olid küll kõik kolm jälle koos, mees keelas aga, et teine teist ei hakanud sööma ja murdma. E 54846 kogumiskoht teadmata (1920?).

Siintoodud teksti on esitanud üks jutustaja, mõistatusele omane dialoogivorm (küsija esitab küsimuse / vastaja vastab) puudub täielikult.

Samas leidub Kirjandusmuuseumi mõistatuste paberkartoteegis (sisaldab alates 19. sajandi teisest poolest tänaseni ligikaudu 175000 üleskirjutust) umbes 30 küsimus-vastus-vormilist teksti, mille süžeeskeem on sarnane eespool toodud rahvajutu süžeega. Selle mõistatustüübi tegelastel tuleb lahendada küsimuspooles esitatud ülesanne - ületada veetakistus (jõgi, oja), jõuda ühelt kaldalt teisele. Tegelaste kasutuses on küll veesõiduk (paat, parv, lootsik, 


\section{Piret Voolaid}

küna), ent kõik ühel kaldal olijad ei mahu liiga suure raskuse tõttu ühekorraga sellesse. Tegelaskujud võib tinglikult jagada subjektideks, kes oskavad veesõidukit kasutada, olles ühtlasi aktiivsed tegelased, ning objektideks, kes on subjektide vastutusalused, olles ühtlasi passiivsed tegelased, kuid võivad osutuda üksteise elule ohtlikuks. Eesti materjali (nii mõistatuste kui ka juttude) hulgas on levinud just seesama ATU 1579 variant, milles subjekt on mees (paadimees, taat, poiss, talumees, kalamees, kaupmees). Objektid on hunt (koer), kits (lammas, oinas, sokk, jänes) ja kapsapea, moodustades ühtekokku toitumisahela. Veetakistus (jõgi, oja) võib varieeruda, samuti nagu tegelased ja nende arv.

Selle tüübi varaseim kirjapanek eesti mõistatuste paberkartoteegis on trükisepõhine, pärinedes 1918. aastal Tallinnas I. [Joosep] Prümmeli sulest ilmunud väljaandest Lõbus rehkendaja. Ülesannete raamat. Laste arusaamise, mõtteteravuse ja isetegevuse edendamiseks. 82-leheküljelise teose eessõnas "Matemaatika kasvatusteaduse edendamine" avab raamatu autor, kes ametilt ajakirjanik ja õpetaja (EAT: 244), oma eesmärgi:

Naljakujulisi ja tegeliku elu aladelt võetud ülesandeid tuleb tarvitada kui kasvatusteadlist abinõu, et lastes matemaatika vastu huvitust ja kaasaelamist virgutada. Raamat pü̈̈ab selleks võimalust anda ilma sunduslise jõupingutuseta, iseseisva, loova, ühtlasi ka meeltlahutava tegevuse abil arusaadavateks ja tarvitavateks tehes kõige tähtsamad matemaatika algmõisted ja reeglid (Prümmel 1918: 17).

Niisiis on autori eesmärk nagu paljude teistegi samalaadsete teoste puhul (nt Nugis 1939) kuiv matemaatika lõbusate ja põnevate ülesannetega õpilastele huvitavaks muuta. Lihtsamat aritmeetika tundmist ja loogilist mõtlemist vajavaid ülesandeid on raamatus ühtekokku 214. Raamatu neljandast peatükist "Raskest seisukorrast väljapääsemine" leiame ka ATU 1579 süžeega ülesande.

Talumees pidi hundi, soku ja kapsad paadiga üle jõe viima. Paat oli aga nõnda väike, et ühekorraga mees enesega ainult kas hundi üksi ehk soku või kapsad võis paati võtta. Mees mõtles: "Võtan kapsad kaasa, - jätan hundi ja soku mahasööb hunt soku ära. Viin hundi üle, paneb sokk selle ajaga kapsad nahka." Pika arupidamise järele tuli mees hea nõu peale ja viis kõik ilusti üle. Kuidas läks see korda? 
Esiteks viis kitse üle; teisel korral - hundi, kitse tõi tagasi. Kolmandal korral viis kapsad üle, tuli siis tühjalt tagasi ja viis neljandal puhul kitse üle (Prümmel 1918: 36, 76 (66)).

Samalt leheküljelt leiame koostaja Joosep Prümmeli väga huvipakkuva joonealuse märkuse.

Seda ülesannet tuntakse üle tuhande aasta. Ta olevat juba keiser Karl Suurele (768-814) tuttav olnud. Raamatu kokkuseadja (Prümmel 1918: 36).

Arhailine rahvusvaheline tüüp on ATU-kataloogi järgi tuntud üle maailma, lisaks Euroopale levinud näiteks Aafrikas ja Araabias.

Samalaadne ülesanne on avaldatud ka mitmesugustes hilisemates lasteajalehtedes-ajakirjades, nagu näiteks ajakiri Ronk $\mathrm{nr} 19 \mathrm{ja}$ 20 (1924), ajakiri Pioneer nr 12 (1957), ajaleht Säde nr 11 ja 15 (1950) ja nr 71 (1965). Viimati mainitud 1965. aasta Sädemes nr 71 ilmunud nuputamisülesandes on selle ülesande tegelasteks mehe, hundi, kitse ja kapsapea asemel isast, emast, pojast ja tütrest koosnev perekond.

Nuputage! Isast, emast, pojast ja tütrest koosnev perekond jõudis jalutuskäigul jõe äärde. Tuli ületada jõgi, üle jõe aga polnud ei silda ega purret. Ühtki paadimeest ega ülevedajat polnud ka näha. Mis teha? Lõpuks leidis isa põõsastest väikese paadi, mis oli vist laste jaoks ehitatud. Kui isa paati istus, vajus sõiduriist nii sügavale, et keegi teine enam paati minna ei tohtinud. Kui ema proovis, juhtus sama lugu. Ainult kaks last võisid koos paati istuda. Ema ütles: "Sellest pisikesest paadist pole meil kasu, sellega me kõik korraga üle sõita ei saa." Aga isa arvas: "Kui kavalasti teha, võime kõik selle paadiga teisele kaldale pääseda. Me kõik oskame ju aerutada." Isal oli õigus. Kogu perekond võis selle väikese paadiga üle jõe pääseda. Kuidas oli see võimalik? Kes sõitis esimesena üle? Kes tõi paadi tagasi?

Ülesande vastust lehelugejale ei anta, ATU 1579 süžeemotiiv - analoogne veetakistuse ületamine - võimaldab pidada sedagi teksti sama tüübi redaktsiooniks.

Selle tüübi varaseim mõistatusvormiline arhiiviüleskirjutus pärineb 1922. aastast Walter Andersoni kogust. Tartu Tütarlaste Güm- 


\section{Piret Voolaid}

naasiumi 2.a klassi 14-aastase õpilase Loode Munna kirjapanek sisaldab pelgalt küsimust.

Mõista, mis see on? - Kalamees pidi hunti, oinast ja kapsapää üle oja viima, kuidas ta neid viis? Kui kalamees oleks hundi enne viinud, siis oleks oinas seni kapsapää ära söönud, kuidas ta neid üle viis, et nad kõik kolmekesi ilusti üle saaks. Sest ainult üks asi mahtus lootsikule (A I 159 (18) < Tartu (1922)).

Kuigi vanim kirjapanek pärineb trükisest, ei julge selle tüübi levikut päris kindlalt kirjandusemõjuliseks sekundaartraditsiooniks pidada. Probleem, miks see mõistatusjutt pole varem arhiivi jõudnud, võib olla kogumise juhuslikkuses. L. Munna tekstil ei näi J. Prümmeli tekstiga otsest seost olevat (erinevad tegelaskujude nimetused), mistõttu on raske midagi kindlat väita. Selle mõistatustüübi ühtekokku 21 üleskirjutust on arhiivi jõudnud ajavahemikul 1922-1996, 1992. aasta koolipärimuse kogumise käigus laekus arhiivi 14 ATU 1579 süžeega kirjapanekut.

\section{Tüüp ATU 1579 digitaalses andmebaasis Eesti piltmõistatused}

Folkloorsed motiivid on sageli ajas väga kohanemisvõimelised, sobitudes uuematesse hilistekkelistesse vormidesse. Kui 1980. aastatel võitsid esmajoones eesti kooliõpilaste hulgas populaarsuse piltmõistatused, siis on näiteks vaatlusalust mehe, hundi, kitse ja kapsapea lugu mõnel puhul pildiga ilmestatud ja tüübi ATU 1579 kolm visuaalselt kujundatud üleskirjutust võib leida ka piltmõistatuste arvutiandmebaasist (http://www.folklore.ee/Reebus). Kõnealusel juhul on tegu ühe tekstilise jutu- või mõistatustüübi edasiarendusega, kohandamisega mõistatuse kui folklooriliigi ühte hilistekkelisemasse - piltmõistatuse - vormi. Ilmselt just seetõttu jääb ATU 1579 pildiline realiseering omapäraseks tekst- ja piltmõistatuse vahevormiks.

Kui piltmõistatuse visuaalsel kujutisel on tavaliselt mõistatuse äraarvamisel ülioluline roll, siis siin on küll ükskõik, kas jõge, paati, meest, hunti, kitse ja kapsapead joonistatakse või mitte, lahenduse leidmiseks piisab mõistatuse küsimuspoole (jutu) tähelepanelikust kuulamisest. Ometi on see mõistatus ärgitanud ennast visuaalselt kujundama. 
Piret Voolaid

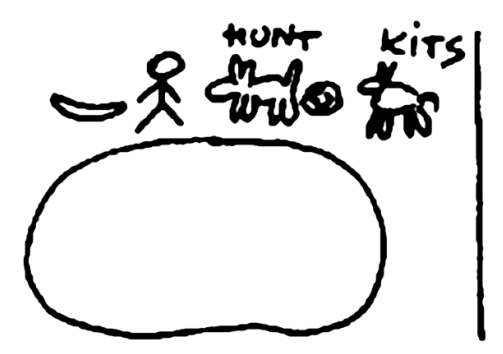

Kuidas saab mees viia üle järve hundi, kitse ja kapsa? Mida peab tegema mees? - Algul viib mees paadiga üle järve kitse, sellepärast et hunt kapsast ei sö̈o. Mees sõidab paadiga tagasi ja järgmisena viib kapsa üle. Tagasi tulles toob uuesti kitse tagasi. Siis võtab hundi ja viib üle järve. Teisele poole järve on viidud kapsas ja hunt. Nüüd mees läheb ja toob kitse ka üle järve (RKM, KP 19, 278 (5) < Märjamaa keskkooli 10. kl õpilane (1992)).

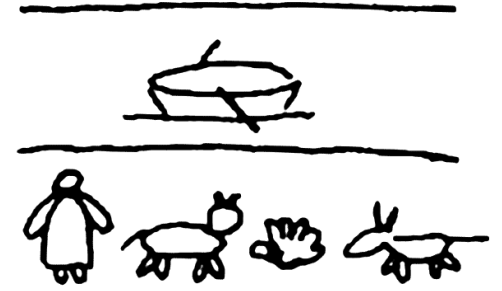

Vanamehel on vaja üle jõe viia oinas, kapsas ja hunt. Kuidas ta saab need üle jõe, kui paati läheb üks korraga? - Ta viib enne oina üle, siis ta viib hundi ja toob oina tagasi, siis ta viib kapsa ja siis tuleb uuesti oinale järele (RKM II 347, 222/3 (28) $<$ Räpina khk, Veriora as - Mall Hiiemäe < Andres Külaveer, 7 a (1980)).

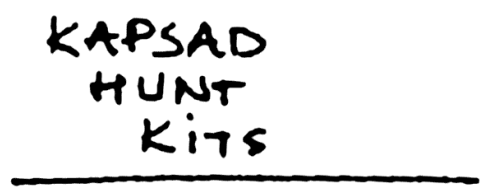

Kuidas mees saab viia kõik üle järve, et nad üksteist ära ei sööks? Üks mahub korraga peale. - Kõigepealt viib kitse üle, 


\section{Piret Voolaid}

siis hundi, toob kitse tagasi. Viib kapsad üle ja siis kitse (RKM, KP 36, 111 (16) < Tartu 2. keskkooli 7. kl - Nele Rägo (1992)).

Selle mõistatuse illustreeritud variante esineb ka meie põhjanaabritel soomlastel. Ulla Lipponen on 1986. aastal kogutud koolipärimuse põhjal koostanud kogumiku Kilon poliisi ja muita koululaisvitsejä, millest ei puudu ka tüüp ATU 1579 (Lipponen 1988: 39). Seda Kuopiost üles kirjutatud teksti illustreerib pilt.

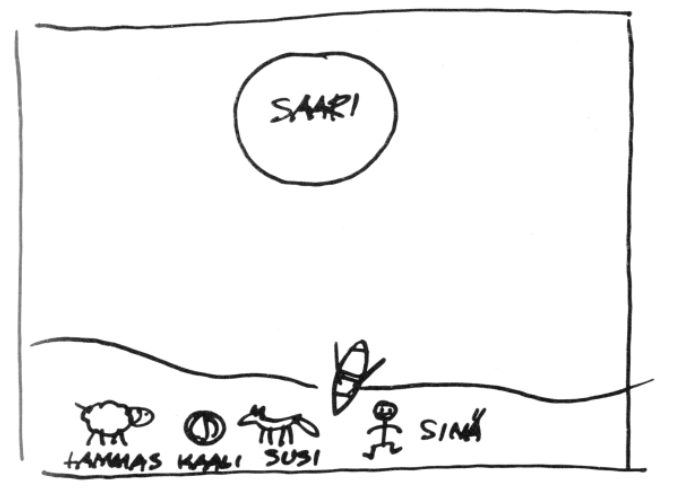

Sul tuleb paadiga viia KAPSAS, HUNT ja LAMMAS saarele nii, et hunt ei saaks lammast ega lammas kapsast ära sü̈̈a. Kuidas toimid? - Esmalt vii saarele lammas. Seejärel vii hunt ja jäta ta saarele. Vii lammas teisele kaldale tagasi. Jäta lammas kaldale ja vii kapsapea saarele hundi juurde. Tule nü̈̈d lambale järele ja vii ka tema saarele (autori tõlge).

Adaptsiooninähtusena ilmnevad selle teksti juures lokaalsed iseärasused: tuhande järve maal eelistatakse saart, Eesti redaktsioonis aga teed jõe ühelt kaldalt teisele.

Niisiis sobivad selle süžee väljendamiseks mõlemad, nii jutuvorm kui ka mõistatuse küsimus-vastus-vorm, mida mõnel juhul pildiga illustreeritakse. Võib vaid oletada, kas mõistatuste puhul on tegemist jututeksti "teise eluga" (vrd Honko 1998: 77) muus pärimusliigis, kuid vähemalt tänapäeval tundub ilmselgelt domineerivat loogikaülesanne. Näiteks eeltoodud soome tekstis puudub küsimuses tähelepanu juhtimine sellele, et paati mahub vaid kaks tegelast 
korraga, ilmselt on see traditsioonist juba immanentselt teada. Veetakistuse ületamist aga saab üha uuesti ja uuesti lahendada.

\section{Tüübi ATU 1579 sinasõprus internetiajastuga - folkloor või folklorism?}

\section{Arhiveerimise argipäev}

Arhiivitehniliselt on peaaegu saja aasta vältel kogutud tüübi ATU 1579 üleskirjutused nii eesti käsikirjalistest kogudest kui ka erinevatest trükistest koondatud paberkartoteeki, kust need digiteeritakse. Tekstiandmebaaside rajamisega kaasnevad uued proovikivid - ammendavate andmebaaside puhul tuleb käsikirjalistele tekstidele ideaalis lisada ka "digitaalselt sündinud" materjal. Internetikeskkond on saanud viimasel kümnendil ammendamatuks materjaliallikaks paljudele humanitaarteadlastele - folkloristidele, lingvistidele, psühholoogidele, sotsioloogidele jpt. Internetikeskkonnas on sündinud palju uut ajastu- ja kultuuriomast folkloori, mille eeliseks võrreldes arhiivides leiduva folkloorse materjaliga on protsessisidusus. Uurija, kes töötab arhiivimaterjaliga, töötab staatilise, kasutuskontekstist eraldatud ainega, internet kui kommunikatsioonimeedium aga võimaldab uurida ühiskonda, mis tähendab protsessi jälgimist (Runnel 1999: 19). Kui ATU 1579 süžeega tekste on eesti arhiivimaterjali hulgas umbkaudu 30 (kogutud mõistatuste üldarvu 175000 põhjal otsustades ei peegelda see kõnealuse tüübi kuigi suurt tuntust, ent väga sageli kajastab arhiiviüleskirjutuste hulk vaid rahvapärimuse kogumist, mitte aga adekvaatset levikut), siis internetiajastul on sellel süžeel olnud folkloristlikus mõttes põnev saatus ja lai levik. Arhailised folkloorsed motiivid võivad internetikeskkonnas saada uue kuue, ning ka ATU 1579 süžeesse kätketud skeem on andnud inspiratsiooni interaktiivsete mängude loojatele ja need mängud on omandanud arvutimängurite hulgas suure populaarsuse. Eesti rahvaluule digitaalsetes andmebaasides ei kajastu see rohkearvuline mängumaterjal aga kuidagi, erinevalt "digitaalselt sündinud" netinaljadest (vt Laineste 2004: 15-16; 2122 ja andmebaas Eesti kaasaegsed anekdoodid veebiaadressil http:/ /www.folklore.ee/ liisi/o2/). Arvutimänge kui pärimusdokumenti ei saa praegu "kinni püüda" ega andmebaasi tõsta, aga probleem on olemas ja ilmselt leiab tulevikus lahenduse. 


\section{Piret Voolaid}

\section{Folkloor ja folklorism ATU 1579 kontekstis}

Dünaamiliste folklooriprotsesside jälgimisel on eri uurijad kasutanud erinevaid mõisteid. Kui Regina Bendix vaatleb oma uurimuses Autentsuse otsinguil (In Search of Authenticity) analüütilisi mõisteid folkloor ja folklorism (Bendix 1997: 176-187), viitab ta Hans Moserile, kes 1962. aastal käsitleb uurimuses "Folklorismist meie ajal" (Vom Folklorismus in unserer Zeit) folklorismi mõistet. H. Moserilt pärineb ka tõlgendus sekundaarfolkloor (secondhand folklore) justkui tõelisest folkloorist võõrandumise tähistuses. Folkloori kasutamise ilmingud algkontekstist erinevas kontekstis on $\mathrm{H}$. Moseri järgi folklorism, mida ta määratleb kolme põhipostulaadiga:

1) traditsiooniliselt ja funktsionaalselt määratletud rahvakultuuri elementide esitamine selle kultuuri ja ühiskonnaklassi piiridest väljaspool;

2) pärimusmotiivide mängulised jäljendusviisid teistes sotsiaalsetes kihistustes;

3) väljaspool traditsiooni esinevate folkloorisarnaste elementide eesmärgipärane leiutamine ja loomine.

Selle määratluse järgi võib aja jooksul iga edasiarenevat teisenenud folklooriüksust (nt süžee, motiiv), mis oma sünni- või algkujust natukenegi erineb, pidada folklorismi ilminguks. Ka Lauri Honko nendib, et $\mathrm{H}$. Moseri määratluse kohaselt õigustab algupärasest erinev keskkond esituse üleviimist folklorismi kategooriasse (Honko 1998: 78), kuigi ta ise soovitab hinnata ja uurida folkloori teise elu sündmusi vastavalt nende vaieldamatule kultuurilisele väärtusele. Teisisõnu on folklorism folkloori kaasnähtus (käsitatav isegi kui folkloori alaliike (Kuutma 1998: 6), aga samas võib tuttavast pärimuskeskkonnast väljunud pärimustekst kujundada uue pärimusrühma, nt netimängurid, kes levitavad mängu (või teavet mängu kohta) üksteisele, kes mängivad seda koos, luues mängusituatsioone jne (vrd Dundes 2002: 102).

Teooria järgi sobib folklorismi faasi jõudvate nähtuste hulka ka tüübi ATU 1579 süžee, mis on aegade jooksul oma vormi ja funktsiooni kohandanud vastavalt keskkonnale, ilmutades uutesse kihistustesse ladestumise ja tugevate funktsioonimuutustega folklorismipäraseid omadusi. Siinkohal on õigustatud küsimus: millal ATU 1579 süžee nüüdisaegne laialdane interaktiivne rakendamine kuulub folkloori, millal folklorismi vaatevälja? Ehkki folkloori ja folklorismi vahele on raske täpseid piire tõmmata, aitab see folk- 
loori kaasnähtus jälgida vaatlusaluse tüübi dünaamilisust. Süžee, mille puhul tuleb ühel pool jõge viibijail etteantud tingimustel veetakistus ületada, on äratuntavalt sama nii M. J. Eiseni kogust pärit narratiivis (vt eespool E 54846), 20. sajandi algusest alates üleskirjutatud küsimus-vastus-vormilistes tekstilistes ja piltmõistatustes kui ka infotehnoloogia-ajastul loodud interaktiivses arvutimängus.

Kui ATU 1579 oletatav esmane funktsioon on küsija ja vastaja dialoog, mille kestel vastaja (juhul kui ta pole varem küsimust kuulnud) peab oma loogilist taipu teritama ja ülesande tulemusliku strateegia leidma, annab just arvutikeskkond sellele arhailisele tüübile veel ühe funktsiooni. Et mingi süžee arvutimänguks saaks, peab kõigepealt programmeerija idee tehniliselt lahendama. Loogikaülesandena ongi see süžee heaks õppematerjaliks arvutiteaduse tudengitele. Näiteks Londoni Keiserliku Kolledži (Imperial College London) õppejõud Michael Huth kasutab programmeerimise loogiliste aluste (Logical Foundations of Programming) õppematerjalides (Huth 2005) just ATU 1579 süžee realiseerimist arvutimänguna. Kasutades SMV-modelleerimiskeelt, kirjutatakse selle ülesande lahendamiseks programm. Sellistel puhkudel pole enam oluline ülesande tekstis antud küsimuse enda lahendamine, vaid juba interaktiivsel kujul lahendi esitamine mängijale. Mõistatuse sisu saab matemaatilise tehnoloogiakeele õppimise vahendiks ja on sel puhul ehe folklorismiilming.

Kas saab aga ehedaks folklorismiks pidada mängijale kätte antud arvutimängu ennast? Või kas saab mängu puhul ka folkloorseid tahke tuvastada? Folkloristlikku ja folklorismilikku liikuvat vahekorda võiks väga üldiselt kujutada skeem lk-1 88.

\section{ATU 1579 elu arvutimänguna}

2003. aastast alates on eesti arvutimänguhuvilistele avatud rohkel arvul online-mänge koondav veebisait "Mängukoobas" (joonis 1) aadressil http://mangukoobas.lahendus.ee, kus saab valida actionja seiklusmängude, nupu- ja strateegiamängude, laua- ja kasiinomängude, spordimängude, Multyplayer-mängude ja naljafilmide vahel. Lehekülg on laste ja noorte hulgas väga populaarne, oktoobris 2003 leidsid netikasutajad veebilehe üles, sama aasta jõuluks oli 


\section{Piret Voolaid}

\begin{tabular}{|c|c|c|}
\hline Folkloor & Folklorismi ilmingud & Folkloor \\
\hline $\begin{array}{l}\text { ATU } 1579 \text { süžee } \\
\text { pärimuskontekstis } \\
\text { (enne arvutite kasu- } \\
\text { tuselevõttu). Nii nar- } \\
\text { ratiivi kui ka mõis- } \\
\text { tatuse küsimus- } \\
\text { vastus-vormis süžee } \\
\text { levib põlvkondade } \\
\text { vältel kasutajalt } \\
\text { kasutajale tradit- } \\
\text { sioonilise folkloori- } \\
\text { na. Teksti puhul on } \\
\text { oluline leida küsimu- } \\
\text { sele õige lahendus. } \\
\qquad\end{array}$ & $\begin{array}{l}\text { ATU } 1579 \text { süžee in- } \\
\text { fotehnoloogiaõppurite } \\
\text { õppevahendina. Folk- } \\
\text { loorne tekst on baa- } \\
\text { siks, selle puhul on } \\
\text { küsimusele õige la- } \\
\text { hendus niigi teada. } \\
\text { Küsimus-vastusvor- } \\
\text { milise teksti funkt- } \\
\text { sioon on muutunud: } \\
\text { programmeerija } \\
\text { ülesanne on transpo- } \\
\text { neerida see tarkva- } \\
\text { raliste vahenditega } \\
\text { visuaalselt paelu- } \\
\text { vasse interaktiivse } \\
\text { arvutimängu vormi. } \\
\quad \rightarrow\end{array}$ & $\begin{array}{l}\text { ATU } 1579 \text { süžee ar- } \\
\text { vutimänguna taas } \\
\text { pärimuskontekstis. } \\
\text { Visuaalse interaktiiv- } \\
\text { se mängu levikukesk- } \\
\text { kond on füüsiliselt } \\
\text { piiratud arvutiga. Te- } \\
\text { kib vähemalt kaks } \\
\text { folkloorset keskkon- } \\
\text { da: (1) mängijate kui } \\
\text { uue pärimusrüh-ma } \\
\text { keskkond ja (2) ka- } \\
\text { sutaja võib levitada } \\
\text { süžeed ka traditsioo- } \\
\text { nilise suulise ja/või } \\
\text { kirjaliku folkloorina. } \\
\text { Teksti puhul on taas } \\
\text { oluline leida küsimu- } \\
\text { sele õige lahendus. }\end{array}$ \\
\hline
\end{tabular}

Skeem 1. Folkloori ja folklorismi tinglikud vahekorrad ATU 1579 süžee kasutusfaasides.

leheküljel 8000 ja 2004. aasta juuniks 37000 kasutajat (Sarv 2004: 16). Selle portaali rajaja Anton Sinioru (OÜ Dermild) väitel on neist lõviosa 5-16-aastased. Mänguportaal sai loodud lihtsalt lõbu pärast - et loojatel endal oleks põnev (ibid.). Registreeritud kasutajaid nimetatakse koopakollideks, kelle hulk kajastub esilehel. Reaalajas võib jälgida, kui palju on mingil konkreetsel hetkel parajasti mänguhuvilisi tegutsemas. Kasutajad saavad ise mänge portaali lisada, iga mängu juurde avatakse foorum, kus neil on võimalik suhelda ja kommentaare avaldada.

Juulis 2004 on portaali kasutaja, kelle varjunimi on Zakuzaku, lisanud mängu "Hunt, lammas ja kapsad". Nupu-ja strateegiamängude saidis asuvat mängu, mille kood on 48601, iseloomustatakse järgmiselt:

Vana hea nuputamismäng nü̈̈d ka arvuti peal ... pead viima hundi, lamba ja kapsad paadiga üle jõe (http://mangukoobas. lahendus.ee/ index.php?0035486015). 
Viidatud link juhatab küll Plastelina loogikamängude (Plastelina Logic Games) leheküljele veebiaadressil http://www.plastelina.net/ games/game1.html (joonis 2a), mis ei asu Eesti domeenis (portaal on inglise, saksa, hispaania ja portugali keeles), ent süžee ATU 1579 on eesti lastele Flash Shockwave' ${ }^{3}$ ja JavaScripti ${ }^{4}$ arvutimängu kujul kättesaadav. Mängukoobas loendab ka eri mängude kasutuskordi, 5. aprilliks 2005. aastal (artikli kirjutamise ajaks) oli "Hunti, lammast ja kapsaid" mängitud 14066 korda. Arv ei näita küll kasutajate täpset hulka, kuivõrd sama kasutaja võib mängu külastada ükskõik mitu korda. "Hunt, lammas, kapsad" on tegelikult selle mängu lihtsaim tase, kui mängija sellega toime tuleb, saab ta järgmisele tasemele (joonis $2 b$ ), kus mängija ülesandeks on toimetada üle jõe kolm inimsööjat ja kolm misjonäri. Tähelepanu tuleb aga pöörata asjaolule, et kui ühele jõekaldale jääb inimsööjaid enam kui misjonäre, kugistavad inimsööjad misjonäri(d) alla. ATU 1579 misjonäride ja inimsööjate versiooni lahendamise järel on võimalik proovida oma võimeid veelgi keerukamatel tasemetel.

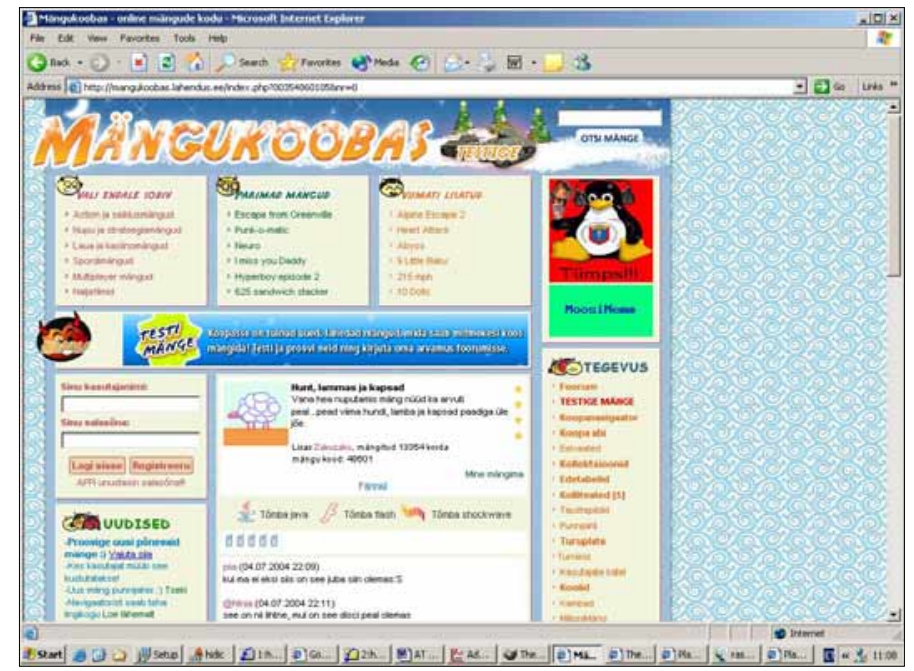

Joonis 1. Eesti laste hulgas populaarne arvutimängude veebisait "Mängukoobas" (Mängukoobas 2005), millelt on näha viide mängule "Hunt, lammas ja kapsad" (ATU 1579). 


\section{Piret Voolaid}

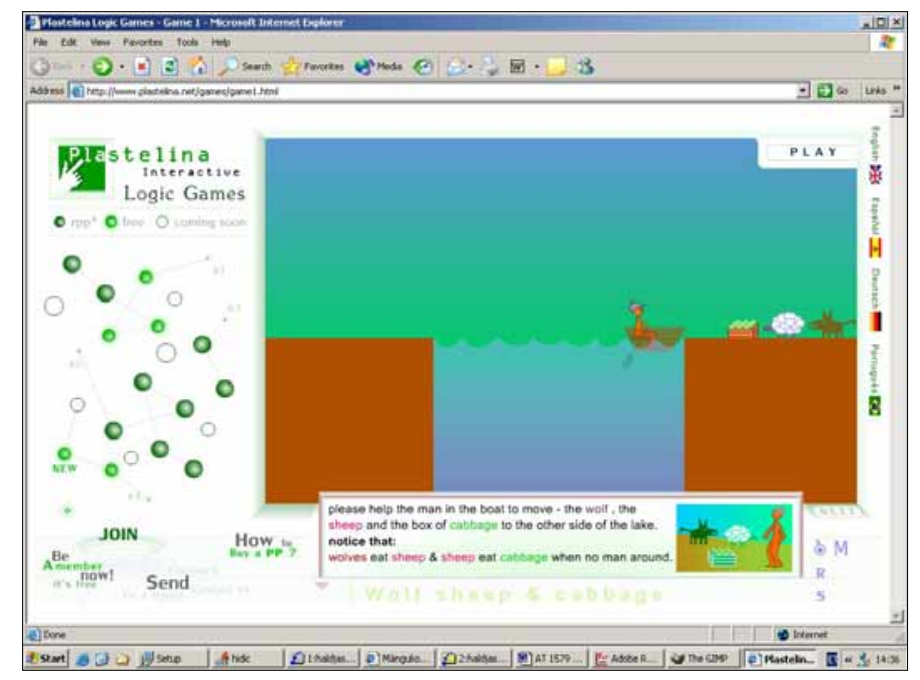

Joonis 2a. Mängukoopast viidatud ATU 1579 süžeega ingliskeelne mäng asub veebiaadressil http://www.plastelina.net/games/game1.html (Plastelina 2005).

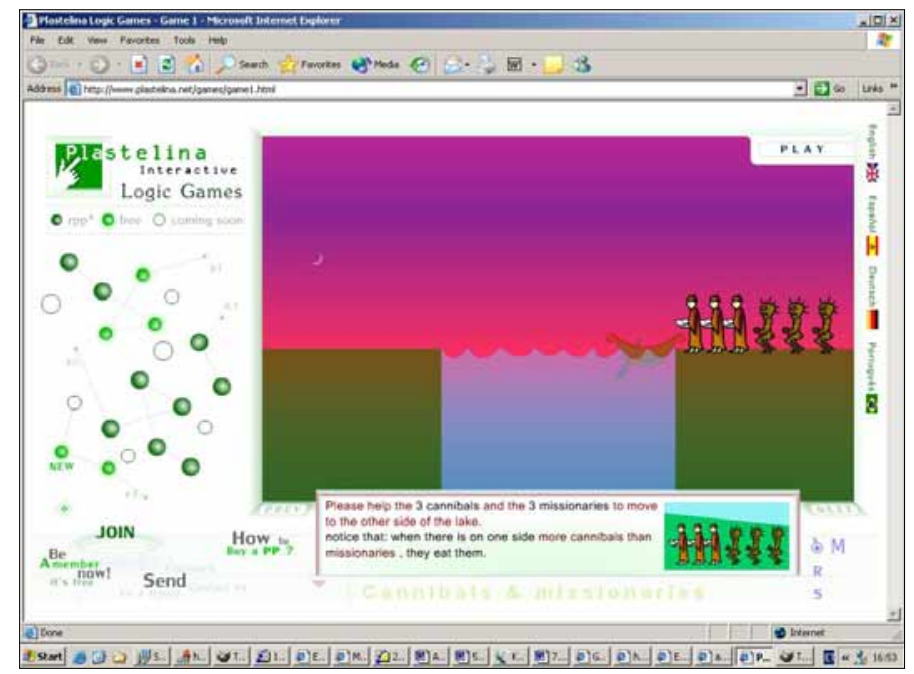

Joonis 2b. Mängukoopa "Hundi, lamba ja kapsa" mängu keerukam tase üle jõe tuleb toimetada kolm inimsööjat ja kolm misjonäri (Plastelina 2005).

wrwr.folklore.ee/tagused 
Täpselt sama mäng on mängimiseks avatud ka teises eesti noortele ja lastele mõeldud populaarses meelelahutusportaalis aadressil http://games.kuuluta.com/onlinefoorum.php?mis=1006\&mislk=2 (games.kuuluta.com 2005). Selle kodulehe registreeritud külastajaid nimetatakse tiigriteks, sarnaselt eelmise portaaliga on neilgi võimalus mänge ise kommenteerida.

Ent samasisulisi animeeritud interaktiivseid internetipõhiseid arvutimänge leidub väga palju ka mujal (vt nt joonised 3-5).

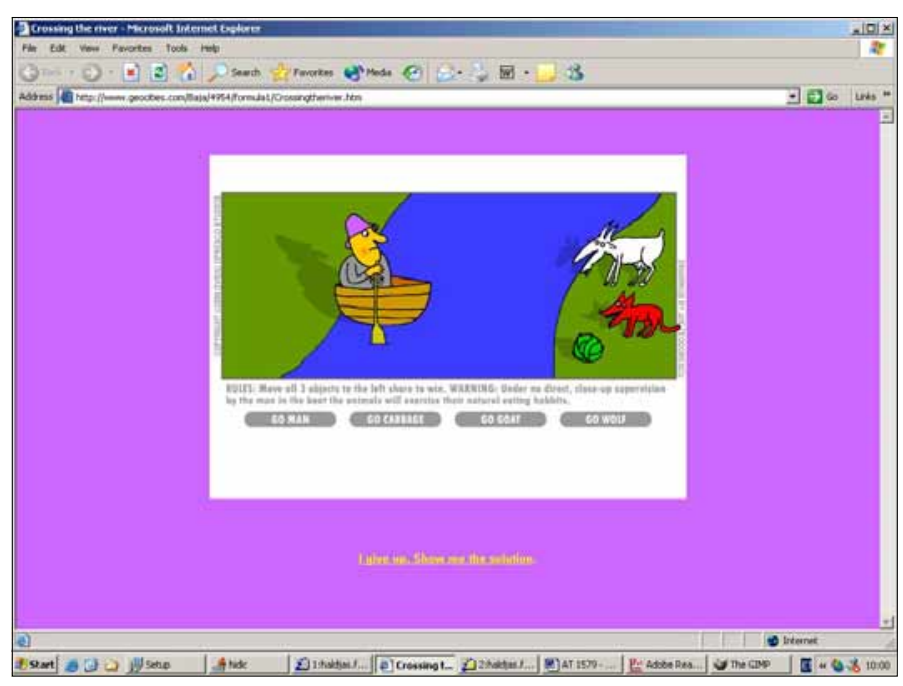

Joonis 3. Animeeritud interaktiivne versioon mõistatusest ATU 1579 veebiaadressil http://www.geocities.com/Baja/4954/formula1/Crossingtheriver.htm (Crossingtheriver 2005).

Veebiaadressil http://www.sandstorming.com/dump/other/river IQGame.swf(River IQ Game 2005) asub Shockwave Flashi vormingus rahvusvaheliselt levinud intelligentsustest ehk IQ-mäng (joonis 6a), mida kasutatavat Jaapanis ka tööintervjuudel (vt alljärgnev kiri). Teave selle mängu kohta jõudis minuni 2005. aasta veebruaris internetifolkloorile tüüpiliselt ühe meililisti (milles on 25 liiget) kaudu. ${ }^{5}$ Kiri teemaga Fwd: Fw: natuke peamurdmist :o) sisaldas lühikest eestikeelset ülesannet ja veebiaadressi: 


\section{Piret Voolaid}

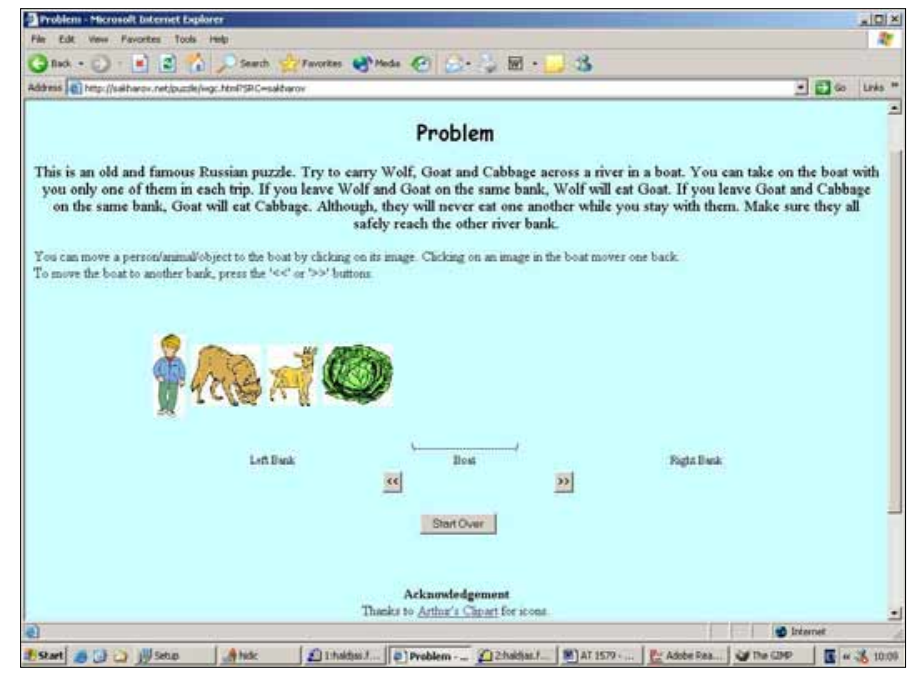

Joonis 4. Animeeritud interaktiivne versioon mõistatusest ATU 1579 veebiaadressil http://sakharov.net/puzzle/wgc.html?SRC=sakharov (Sakharov 2005).

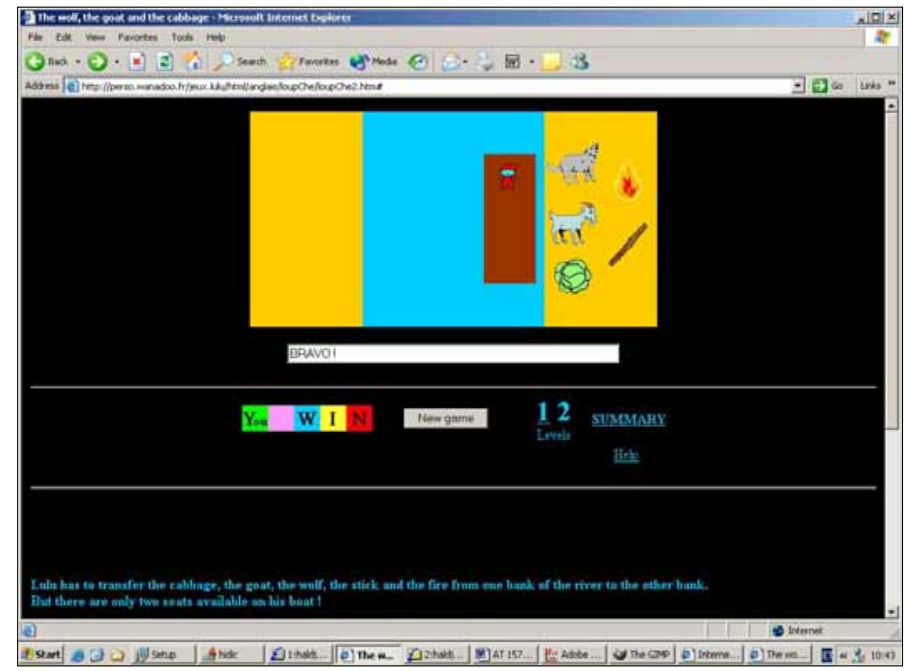

Joonis 5. Suurema tegelaste arvuga animeeritud interaktiivne versioon mõistatusest ATU 1579 veebilehel http://perso.wanadoo.fr/jeux.lulu/html/anglais/ loupChe/loupChe2.htm\# (Lulu Games 2005). 
Jaapani intelligentsustest, mida kasutatakse ka tööintervjuudel. Eesmärk on toimetada kogu seltskond üle jõe.

Mäng algab, vajutades sinist ringi. Parve liigutatakse, klikkides punaseid ringe vaiadel jõe kaldal. Inimesed liiguvad parvele või tagasi maale, kui nende peal klikkida.

Reeglid:

Parvele mahub korraga kaks inimest. Isa ei tohi jätta tüdrukutega, ema peab olema kohal. Ema ei tohi jätta koos poegadega, isa peab olema kohal. Varast (triibulise särgiga) ei tohi jätta ilma politseinikuta ühegi pereliikme seltskonda. Ainult isa, ema ja politseinik oskavad parve juhtida (http://www. sandstorming.com/dump/other/riverIQGame.swf).

Kui ei saa muidu, siis paber-pliiats kätte ning harjutama (Piret Voolaiu erakogu).

Mängu juhend on eesti keelde tõlgitud ilmselt inglise keelest. Kui mängu swf-faili nimega riverIQGame erinevatesse otsingumasinatesse sisestame, genereeritakse meile kõnealuse mängu kohta vastuseks terve hulk veebisaite (Google'i otsingumootor andis näiteks 5. aprillil 2005. aastal 147 vastust). Põnev (vähemalt eesti kontekstis folkloorne) lisamärkus selle mõistatuse kasutamisest Jaapanis tööintervjuudel lausa sunnib küsima "Aga tegelikult...", ent selle intelligentsustesti elu Jaapani kultuurikontekstis oleks omaette intrigeeriv teema.

Ühelt veebilehelt interaktiivses foorumis esitatud ingliskeelne mängureeglistik kattub täpselt eestikeelse kirja sisuga, kuid uudsena on selle lõpus ära toodud testi sooritamise kiirusest johtuvad tulemused.

Result:

if you succeed in

4 minutes: you are a Genius.

6 minutes: You are exceptionally intelligent.

10 minutes: You are very intelligent.

20 minutes: You are average.

25 minutes: You are a bit slow.

30 minutes or more: You are a dumbarse (http://forums.emulatorzone.com/archive/index.php/t-259.html-5. aprill 2005).

Arvutitehnilisi võimalusi kasutades on loodud tüübi ATU 1579 süžee põhjal moodne mõistatusvormiline loogikaülesanne. Tegelaste hulk 


\section{Piret Voolaid}

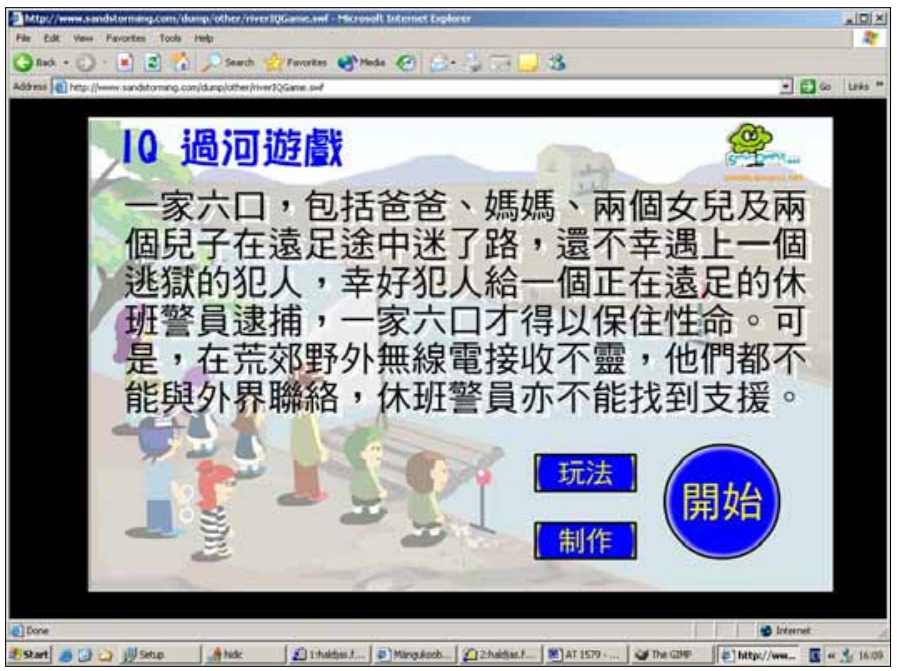

Joonis 6a. ATU 1579 sugemetega "Jaapani intelligentsustest" (http://www. sandstorming.com/dump/other/riverIQGame.swf -5. aprill 2005). Mängu alustamiseks tuleb hiirega vajutada all paremal olevale sinisele ringile (pildil suur ja ümmargune ring).

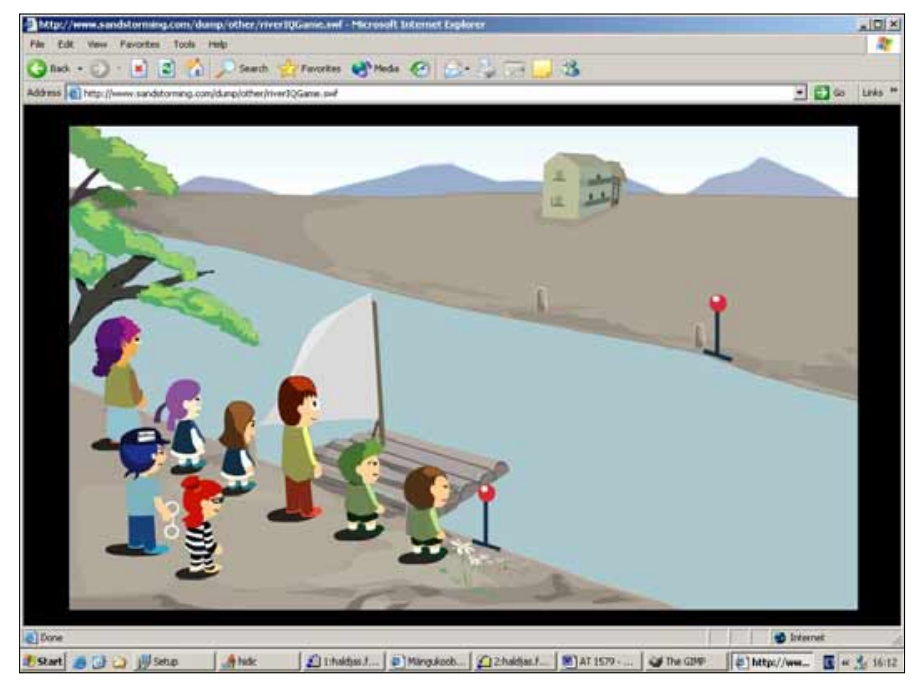

Joonis 6b. "Jaapani intelligentsustest". Ema kahe tütrega, isa kahe pojaga, politseinik ja röövel tuleb parvega üle jõe sõidutada. 
Piret Voolaid

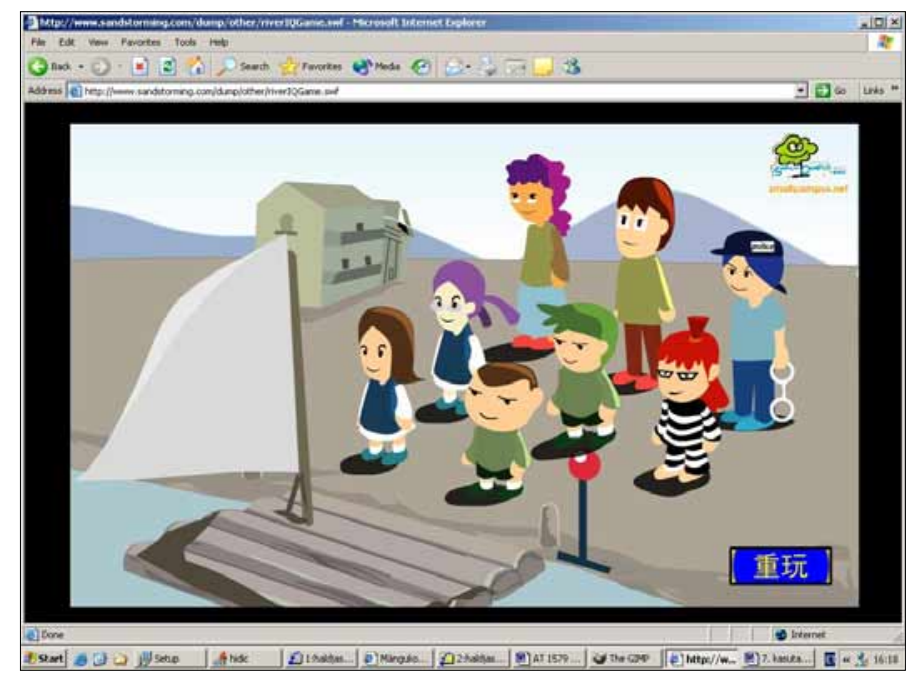

Joonis 6c. "Jaapani intelligentsustest" on edukalt sooritatud, kõik tegelased on onnelikult vastaskaldale toimetatud.

on siin meile enam tuntud mehe, hundi, kitse ja kapsa variandist suurem - selles versioonis tuleb üle jõe aidata ema kahe tütrega, isa kahe pojaga, politseinik ja röövel. Levides kasutajalt kasutajale virtuaalse arvutimaailma kaudu, ületades pildi abil keelebarjääre, kuulub see ülesanne tänapäeva interaktiivse netifolkloori valdkonda.

\section{Kokkuvõtteks}

Aarne-Thompsoni-Utheri jututüübikataloogis numbriga 1579 märgistatud tüüp Hundi, kitse ja kapsapea üle jõe viimine võib küll esineda nii narratiivina kui ka mõistatuse küsimus-vastus-vormis, kuid just viimane loogikaülesandena tundub olnuvat läbi aegade selle süžee tuum. Arvutiajastu tingimustes on traditsioonilisele rahvajutuja mõistatusežanrile lisandunud interneti teel leviva strateegiamängu vorm, milles interaktiivne dialoog leiab aset programmeeritud arvuti (mõistatuse esitaja) ja mängija (mõistatuse lahendaja) vahel. Sama folkloorne süžee on sulandunud uute kultuurikihistustega, uute vormidega ja omandanud lisafunktsioone. 


\section{Piret Voolaid}

Ühtlasi on arvuti ja internet selle süžee levitamisel ja traditsiooni hoidmisel uut tüüpi väga võimas meedium. Ehk tsiteerides Sergei Nekljudovit:

Ei pea olema väga läbinägelik ennustamaks, et järjekordse folklooriparadigma muutuse toovad kaasa (või on juba toonud) arvutitehnoloogia ja internet; ent on võimatu ette arvata nende kvaasifolklooriliste uusvormide arengudünaamikat (Nekljudov 2003: 26).

\section{Kommentaarid}

${ }^{1}$ Sama numbrit kannab tüüp ka varasemas Aarne-Thompsoni (AT) kataloogis.

2 Mõistatuste perifeersetest alaliikidest on valminud internetiandmebaasid Eesti piltmõistatused (http://www.folklore.ee/Reebus (2002)), Eesti (liit)sõnamängud (http://www.folklore.ee/Sonamang (2003)), Eesti keerdküsimused (http://www.folklore.ee/Keerdkys (2004)), Eesti lühendmõistatused (http://www.folklore.ee/Lyhendid (2004)).

${ }^{3}$ Vähe ribalaiust nõudev ja brauserist sõltumatu vektorgraafiline animatsioonitehnika firmalt Macromedia Inc. Kui erinevad brauserid on varustatud vajalike lisanditega (plug-in), kuvatakse Flash-animatsioone ühtmoodi.

${ }^{4}$ Netscape'is välja töötatud skriptikeel, mis võimaldab veebiautoritel luua interaktiivseid veebisaite.

${ }^{5}$ Kui artikli alguses oli väide, et arhiivi kogunenud tekstide arv (u 30) näitab pigem kogumist kui tegelikku levikut, siis nt selle listi ühe kirja kaudu tehakse süžee ATU 1579 tuttavaks juba 25 liikmele, mis potentsiaalselt tähendaks kogumise korral 25 arhiiviüleskirjutust.

\section{Käsikirjalised allikad}

Eesti Kirjandusmuuseumi Eesti Rahvaluule Arhiivi käsikirjalised kogud: E = M. J. Eiseni rahvaluulekogu (1880-1934)

$\mathrm{RKM}=$ Kirjandusmuuseumi rahvaluule osakonna rahvaluulekogu (19451994)

$\mathrm{RKM}, \mathrm{KP}=$ Kirjandusmuuseumi rahvaluule osakonna koolipärimuse kogu (1992)

Piret Voolaiu erakogu - autori valdustes 


\section{Kirjandus}

AT $=$ Aarne, Antti \& Thompson, Stith 1964. The Types of the Folktale. A Classification and Bibliography. FFC 184. Helsinki: Suomalainen Tiedeakatemia, 1964.

ATU = Uther, Hans-Jörg 2004. The Types of International Folktales. A Classification and Bibliography. Based on the System of Antti Aarne and Stith Thompson. II: Tales of the Stupid Ogre, Anecdotes and Jokes, and Formula Tales. Folklore Fellows Communications 285. Helsinki: Suomalainen Tiedeakatemia.

Ben-Amos, Dan 1982. Perinnelajikäsitteet. Järvinen, Irma-Riita \& Knuutila, Seppo (toim). Kertomusperinne: Kirjoituksia proosaperintun lajeistta ja tutkimuksesta. Tietolipas 90. Helsinki: Suomalaisen Kirjallisuuden Seura, lk 11-28.

Bendix, Regina 1997. In search of authenticity: The formation of folklore studies. Madison: University of Wisconsin Press.

Crossingtheriver 2005 (http://www.geocities.com/Baja/4954/formula1/ Crossingtheriver.htm - 5. aprill 2005)

Dundes, Alan 2002. Võltspärimuse sepitsemine. Dundes Alan. Kes on rahvas? Valik esseid folkloristikast. Tallinn: Varrak, lk 88-102.

EAT = Eesti avalikud tegelased: Eluloolisi andmeid. 1932. Tartu: Eesti Kirjanduse Selts.

Eesti kaasaegsed anekdoodid (http://www.folklore.ee/ liisi/o2/ - 5. aprill 2005).

Ehin, Kristiina 2004. Eesti vanema ja uuema rahvalaulu tõlgendusvõimalusi naisuurimuslikust aspektist. Magistritöö. Tartu: Tartu Ülikool. Käsikiri Tartu Ülikooli eesti ja võrdleva rahvaluule õppetoolis.

games.kuuluta.com 2005 (http://games.kuuluta.com/onlinefoorum.php?mis= 1006\&mislk=2 - 5. aprill 2005).

Honko, Lauri 1998. Folklooriprotsess. Mäetagused: Hüperajakiri 6, lk 5684 (vt ka http://www.folklore.ee/tagused/nr6/honko.htm).

Huth, Michael 2005 (http://www.cis.ksu.edu/ huth/301/puzzle.html - 5. aprill 2005).

Krikmann, Arvo 2005. Ütlusfolkloor. Metsvahi, Merili \& Valk, Ülo (koost). Regivärsist netinaljadeni: Sissejuhatus rahvaluulesse. Tallinn: Koolibri, lk 91-99.

Kuutma, Kristin 1998. Folkloorifestivalid kui tänapäeva traditsioon. Magistritöö. Tartu: Tartu Ülikool. Käsikiri Tartu Ülikooli eesti ja võrdleva rahvaluule õppetoolis. 


\section{Piret Voolaid}

Laineste, Liisi 2004. Tegelased eesti etnilises huumoris. Magistritöö. Tartu: Tartu Ülikool. Käsikiri Tartu Ülikooli eesti ja võrdleva rahvaluule õppetoolis.

Lipponen, Ulla 1988. Kilon poliisi ja muita koululaisjuttuja. Helsinki: Suomalaisen Kirjallisuuden Seura.

Lulu Games 2005 (http://perso.wanadoo.fr/jeux.lulu/html/anglais/loupChe/ loupChe1.htm - 5. aprill 2005).

Mängukoobas 2005 (http://mangukoobas.lahendus.ee/index.php?0035486 0105\&nr $=0-5$. aprill 2005).

Nekljudov, Sergei 2003. Vene rahvaluuleteadus ja strukturaalsemiootilised uurimused. Jaago, Tiiu (koost). Pärimus ja tõlgendus: Artikleid folkloristika ja etnoloogia teooria, meetodite ning uurimispraktika alalt. Tartu: Tartu Ülikooli Kirjastus, lk 26-36.

Nugis, Elmar 1939. Ajaviite-taskuraamat: Katsed, kunsttükid, mängud, mõistatused, mitmesugust. Tallinn: [s.n.].

Pioneer 1957, nr 12.

Plastelina 2005 (http://www.plastelina.net/games/game1.html - 5. aprill 2005).

Prümmel, I. [Joosep] [1918]. Lõbus rehkendaja: Ülesannete raamat: Laste arusaamise, mõtteteravuse ja isetegevuse edendamiseks. Tallinn: Rahvaülikool.

River IQ Game 2005 (http://www.sandstorming.com/dump/other/iverIQGame. swf - 5. aprill 2005).

Ronk 1924, nr 19 ja 20.

Runnel, Pille 1999. Välitööde võimalikkusest internetis. Kalmre, Eda (toim). Kuuldust-nähtust. Tänapäeva folkloorist 4. Tartu: Eesti Kirjandusmuuseum, lk 13-30.

Sakharov 2005 (http://sakharov.net/puzzle/wgc.html?SRC=sakharov - 5. aprill 2005).

Sarv, Mari 2004. Mängukoobas aitab vihmast päeva veeta. Päevaleht, 17. juuni, lk 16.

Säde 1950, nr 11 ja 15; 1965, nr 71.

Šmeljova \& Šmeljov 2002 = Шмелев, Алексей \& Шмелева, Елена. Русский анекдот: Текст и речевой жанр. Studia philologica: Series minor. Москва: Языки славянской культуры. 